\title{
Metabolism in replacement chickens at different ratios of arginine and lysine
}

\author{
I. Ibatullin ${ }^{1 *}$, M. Kryvenok ${ }^{1}$, I. Ilchuk ${ }^{1}$, V. Mykhalska ${ }^{1}$, A. Getja ${ }^{1}$, S. Boyarchuk ${ }^{1}$ \\ ${ }^{1}$ National University of Life and Environmental Sciences of Ukraine, \\ Heroiv Oborony St. 15, Kyiv, 03041, Ukraine \\ *Corresponding author E-mail: njk19@ukr.net
}

Received: 09.09.2020. Accepted: 12.10 .2020

\begin{abstract}
The influence of different levels of arginine and lysine in compound feeds of replacement chickens on their growth, development and metabolism was studied. The effective ratio of arginine to lysine in the diets of replacement chickens was experimentally established, which, depending on the rearing period, was: 1.0:1 for 1-3 weeks, 1.1:1 for 4-8 weeks, 1.2:1 for 16 weeks and 1.2:1 for 17-18 weeks. It was found that the change in the ratio of arginine and lysine in poultry diets has a much higher degree of influence on their productivity, digestibility of feed nutrients, assimilation and efficiency of amino acids than changes in the levels of these amino acids. It was found that the ratio of arginine and lysine in the last period of rearing chickens (16-18 weeks) to a lesser extent affects the productivity of replacement young $\left(R^{2}=0.59\right)$ compared to the first $\left(R^{2}=0.96\right)$ and second periods of rearing $\left(R^{2}=0.65\right)$. The growth of replacement young during all periods of the experiment and the nature of the effect of changes in levels and ratios of these amino acids in feed depending on age and productivity, described by a mathematical model with nonlinear characteristics (polynomial trend line), which has a higher value of approximation $\left(R^{2}\right)$ linear dependence. The use of modern modeling methods and the proposed regression equations allow to predict the content of amino acids in feed for replacement young poultry in accordance with the program of their cultivation and amino acid composition of feed.
\end{abstract}

Keywords: Replacement young stock; Essential amino acids; Arginine; Lysine; Prediction; Regression equation

\section{Introduction}

The main task of technologists in the production of livestock products is to provide animals used in the production of a product with energy, nutrients and biologically active substances, in quantities that would fully meet their physiological needs, given the lowest cost of these substances.

Feed protein is one of the most expensive components of the diet of animals, and therefore its excess, as well as deficiency are unacceptable. For effective use of protein in the diet, animal nutrition must be normalized taking into account the biological value of proteins that are part of the protein, especially in the current conditions of poultry production, because modern poultry crosses are selected for high productivity and, consequently, have high levels of metabolism in their body (Jahanian, 2017).

In recent decades, the productivity of laying hens has increased significantly: the number of eggs during the laying cycle has increased and the efficiency of feed nutrients has increased. Poultry feeding specialists must monitor not only the quantitative indicators of protein content in compound feeds, but also the qualitative composition of its proteins, which depends on the content of amino acids in it.

Each protein has a specific conformation in space and this structure determines its physicochemical and biological properties. The spatial structure of a protein is determined primarily by its primary structure the sequence of amino acids in the polypeptide chain. This spatial structure is quite unstable and can change under the influence of external conditions and chemical compounds that surround the protein molecule. Therefore, knowledge of the biological characteristics of amino acids and their structure allows us to predict and predict certain options in protein synthesis in animals (Guoyao, 2014).

Almost half of the amino acids identified in the body of birds can be synthesized in their body due to the restructuring of carbohydrates, fats, organic acids, amino acids, ammonium salts and others. Substitute amino acids include: asparagine, glutamine, glutamic acid, glycine, carnitine, ornithine, taurine (sometimes this list includes proline and serine). Essential amino acids include lysine, methionine, tryptophan, leucine, isoleucine, threonine, phenylalanine, histidine, valine and arginine, which are vital for birds of all sexes and ages groups except arginine and histidine, which are also not strictly non-essential. glycine, which is essential only for young animals (Fouad et al., 2012). Arginine is an essential amino acid for birds because it lacks the urea-forming cycle, so its need for argenine is higher in mammals (Baker, Han, 1994; Cynober et al., 1995).

There is evidence that there is an antagonism between arginine and lysine. The food antagonism of arginine and lysine was first discovered and studied in the 1950s and 1960s. The results of this early study show that the optimal ratio between arginine and lysine should be 0.8 to 1.7 , depending on the level of electrolytes such as sodium, potassium and chlorine in the diet (Balnave and Brake, 2002).

Thus, excess lysine stimulates arginase, increasing hepatic arginine catabolism in the body, causing symptoms of deficiency of this amino acid and can cause decreased productivity. Increasing arginine levels in diet a lysine-rich weakens the depressive response caused by this antagonism (Ertechini, 2006; Renata de Souza Reis, 2012; Labadan, 2001). Excess lysine in feed may increase chickens' need for arginine, and excess arginine may increase methionine requirements (Chamruspollert, 2002). Today it is established that when normalizing the content in feed such essential acids as lysine, methionine with cystine, tryptophan and 
threonine, it is necessary to take into account the content of valine, the lack or excess of which reduces poultry productivity, and the content of arginine, which under certain conditions affects the use in the body of such an important amino acid as lysine.

Deficiency of sulfur-containing amino acids (methionine + cystine) and lysine and threonine is most often observed in poultry feeding, so they are called limiting. Most feeds contain an excess of leucine, isoleucine, phenylalanine and valine, which adversely affects the productivity of poultry. Disposal or use of this excess in the body requires additional energy, which reduces the efficiency of feeding. Lysine affects the absorption of calcium and phosphorus in animals, stimulates the activity of a number of enzymes involved in redox reactions, improves hematopoietic function of the bone marrow (activates hematopoiesis) and the state of the nervous system, is a catalyst for deamination and reamination reactions. amino acids. Lysine belongs to ketogenic and glycogenic amino acids and in case of insufficient nutrition of animals its hydrocarbon part can be converted into acetoacetic acid and acetylCoA with the formation of glucose and ketone bodies: this process is an important source of energy for the bird. It is also necessary for the synthesis of carnitine, which is involved in the transfer of acyl groups of fatty acids from the cytoplasm in the mitochondria. The recommendations of developers of modern poultry crosses regarding amino acid nutrition do not always allow to fully realize the genetic potential of animals due to insufficient knowledge of the influence of amino acids on the synthesis processes in the body (Wecke, 2016). Current research and practical data indicate the need to take into account in the calculation of compound feed recipes for poultry content in them not only critical amino acids, but also the levels of other essential amino acids (Al-Saffar, Rose, 2002; Fatufe, 2004).

In the first months of post-embryonic development in the tissues of chickens there is an intensive accumulation of dry matter, among which proteins predominate. This period is characterized by high activity of all parts of the protein-synthesizing system in the liver and other organs, as well as a sharp increase in DNA content in hepatocytes (Urdaneta-Rincon, Leeson, 2004). Increased DNA levels in chicken liver cells at an early age are accompanied by an increase in RNA content. All types of RNA involved in protein synthesis are synthesized in the liver nuclei of young chickens: informational, transport and ribosomal. Increased concentrations of nuclear RNA in hepatocytes of chickens in the early period of ontogeny are associated with increased protein synthesis in the body. The highest level of RNA in the liver of chickens is observed at one month of age, ie during the period of the most intensive protein synthesis. After one month of age, the concentration of RNA in the liver of chickens decreases slightly (Sklan, Noy, 2003).

It should be noted that the delay in the growth of animals in the early periods of ontogenesis later is not fully compensated. In addition, during compensatory growth in the body of the bird there is an increased deposition of fat and changes in the chemical composition of muscles (Zampiga et al., 2019).

In the study of amino acid metabolism, it is necessary to take into account a number of factors that directly affect the level of their assimilation. Such factors are the age of the bird and its physiological condition, the size of the feed ration and the frequency of feeding, the microclimate of the poultry house, the physical form of the feed.

Unsatisfactory storage, harvesting, processing and heat treatment of feed, the presence of dense polysaccharide shells, low solubility in the gastrointestinal tract and reduced availability of digestive enzymes, different rates of absorption and transport into tissues, as well as antagonism between amino acids.

Therefore, studies to study the digestibility of amino acids in the body of the bird must take into account the influence of these factors and organize the experiments in such a way as to either eliminate this effect, or that it was similar for birds of all groups. Experimental studies show that an excess of some amino acids exacerbates the deficiency of others. Based on an in-depth study of the phenomena of imbalance, it has been established that even a small excess of amino acids in poultry diets can cause a sharp decrease in biosynthetic processes in their body (Zampiga et al., 2018).

Topical issues are both the improvement of feed nutrition assessment systems and the development of recipes for the most effective feed, and new approaches to the normalization of amino acid nutrition of poultry, taking into account both quantitative and qualitative indicators (Kryvenok, 2017).

The bird's need for essential amino acids depends on the level of protein in the diet and can vary widely. The recommendations of some poultry experts state that the ratio of nitrogen and essential and essential amino acids in protein should be constant.

Thus, a decrease in nitrogen levels in the diet should be a proportional decrease in the number of amino acids in these two groups, because the bird's need for protein decreases with age, and therefore the number of amino acids in its diet should decrease in proportion to the amount of protein (Andreas Lemme, 2009; Elliot, 2008 ).

The intensity of protein synthesis of organs and tissues of poultry is directly dependent on the supply of complete protein with feed. When feeding defective proteins to birds, especially in the absence of methionine, lysine, tryptophan, arginine, isoleucine, leucine, valine, phenylalanine and tyrosine in the feed, metabolism is disturbed, growth is slowed down, productivity decreases sharply, there is a deterioration of 2016; Carvalho et al., 2015).

Numerous studies by a number of scientists (Kriukov et al., 1997; Ebrahimi, 2014) have studied changes in the needs of poultry in a particular amino acid depending on time, physiological state, changes in productivity and proposed mathematical methods for determining these needs, including theoretical methods calculations. However, it should be noted that for many wildlife phenomena, random dependencies are more often typical.

Such relationships between two traits occur in the general case when there are certain random factors that affect only the first or second trait. In this case, if one feature changes to a certain value, the other can take different values. Therefore, the aim of our research was to establish the change in the need for lysine in the body of replacement young animals depending on the change in the amount of arginine in their diets.

\section{Material and Methods}

The experiment was carried out by the method of groups (Table 1), according to which 400 chickens of daily age of the cross "Brown Nick" were selected, from which on the principle of analogues formed four groups: control and three experimental, 100 heads in each. The main period lasted 126 days.

Poultry were fed during the accounting period with complete feed balanced according to the existing norms recommended by the cross-country developer, and chickens of the experimental groups were fed feed with different levels of amino acids, the content of which was changed by introducing or excluding their synthetic drugs. Determination of live weight of poultry and feed costs was performed on scales brand AXIS A 5000 IV class. Digestibility of nutrients (organic matter, protein, fat, fiber, BER) was determined according to conventional methods (Kononenko, 2000). 
Ukrainian Journal of Ecology

Table 1. Scheme of scientific and economic experience.

\begin{tabular}{|c|c|c|c|c|c|}
\hline \multirow{2}{*}{$\begin{array}{l}\text { Age, } \\
\text { weeks }\end{array}$} & \multirow[t]{2}{*}{ Indicators } & \multicolumn{4}{|c|}{ Groups } \\
\hline & & 1 & 2 & 3 & 4 \\
\hline $1-3$ & Lysine, \% & 1.20 & 1.1 & 1.20 & 1.3 \\
\hline \multirow{3}{*}{$4-8$} & Arginine, \% & 1.10 & 1.0 & 1.20 & 1.30 \\
\hline & Lysine, \% & 1.10 & 1.0 & 1.10 & 1.10 \\
\hline & Correlation & 1.0 & 1.0 & 1.1 & 1.2 \\
\hline $9-16$ & Correlation & 1.1 & 1.0 & 1.2 & 1.3 \\
\hline \multirow{3}{*}{$17-18$} & Arginine, \% & 0.88 & 0.86 & 0.90 & 0.92 \\
\hline & Lysine, \% & 0.80 & 0.86 & 0.75 & 0.71 \\
\hline & Correlation & 1.1 & 1.0 & 1.2 & 1.3 \\
\hline
\end{tabular}

The obtained materials of experimental studies were statistically processed using arithmetic means (M), root mean square error (m) and the degree of probability of the difference $(p)$ between the indicators. The probability of the difference between the indicators was assessed by Student's test (Lakyn, 1990).

\section{Results and Discussion}

The level of metabolic energy, nutrients and biologically active substances in the feed of experimental chickens varied according to the phase of rearing, and the level of amino acids changes according to the scheme of the experiment. The composition of feed for experimental chickens was traditional, based on grain feed and soybean and sunflower meal. The content of metabolic energy and nutrients for chickens in the experimental group are shown in Table 2.

Table 2. The content of basic nutrients and energy in $100 \mathrm{~g}$ of feed, $\%$

\begin{tabular}{lllll}
\hline Indicators & Age, weeks & & & \\
& $\mathbf{1 - 3}$ & $\mathbf{4 - 8}$ & $\mathbf{9 - 1 6}$ & $\mathbf{1 7 - 1 8}$ \\
\hline Exchange energy, MJ & 1.21 & 1.15 & 1.01 & 1.14 \\
Crude protein, g & 20.0 & 18.5 & 14.5 & 17.5 \\
Crude fiber, g & 5.0 & 5.0 & 7.0 & 5.5 \\
Calcium, g & 1.05 & 1.00 & 0.90 & 2.00 \\
Phosphorus, g & 0.75 & 0.70 & 0.58 & 0.65 \\
Linoleic acid, g & 2.00 & 1.40 & 1.00 & 1.00 \\
Sodium, g & 0.18 & 0.17 & 0.16 & 0.16 \\
Chlorine, g & 0.20 & 0.19 & 0.16 & 0.16 \\
\hline
\end{tabular}

The amount of metabolic energy, the content of nutrients and biologically active substances in $100 \mathrm{~g}$ of feed corresponded to the standards established for replacement chickens cross "Brown Nick" in different periods of their rearing.

The main indicator of productivity of replacement young stock is the increase in its live weight (Table 3), which should change gradually within certain limits, according to the breeding program recommended by the developer of the cross, because too high live weight gain, as well as low, negatively affect chicken productivity. Future. Also, in the period from 9 to 16 weeks of rearing young, it is necessary to use limited feeding (reduce energy and protein in the diet) to prevent premature puberty, which can further adversely affect the reproductive capacity of birds and egg quality.

As can be seen from the Table 3 data, the highest live weight was in chickens of the third group, in whose diets the content of arginine and lysine were higher than in the control, and the ratio between these amino acids was by growing periods: $1.0 ; 1.1 ; 1.2$ and 1.2 , respectively.

Table 3. Productivity and feed costs.

\begin{tabular}{|c|c|c|c|c|}
\hline Indicators & $\begin{array}{l}\text { Groups } \\
1\end{array}$ & 2 & 3 & 4 \\
\hline $\begin{array}{l}\text { Live weight in the experiment, g: } \\
\text { early }\end{array}$ & $71 \pm 1.12$ & $69 \pm 1.23$ & $69 \pm 0.86$ & $70 \pm 0.97$ \\
\hline $\begin{array}{l}\text { at the end } \\
\text { Average daily gain, } \mathrm{g} \\
\text { Feed costs, g: }\end{array}$ & $\begin{array}{l}1460 \pm 8.12 \\
11.0 \pm 0.12\end{array}$ & $\begin{array}{l}1471 \pm 7.21 \\
11.1 \pm 0.11^{* *}\end{array}$ & $\begin{aligned} 1512 \pm 4.79 \\
11.5 \pm 0.17^{* * *}\end{aligned}$ & $\begin{array}{l}1485 \pm 5.18 \\
11.2 \pm 0.14^{*}\end{array}$ \\
\hline $\begin{array}{c}\text { for the whole period } \\
\text { per } 1 \mathrm{~kg} \text { of gain }\end{array}$ & $\begin{array}{l}6450 \pm 22 \\
4417 \pm 11 \\
\end{array}$ & $\begin{array}{l}6453 \pm 17 \\
4387 \pm 14 \\
\end{array}$ & $\begin{array}{l}6441 \pm 11 \\
4259 \pm 16 \\
\end{array}$ & $\begin{array}{l}6462 \pm 12 \\
4352 \pm 22 \\
\end{array}$ \\
\hline
\end{tabular}

$* \mathrm{P}<0.05 ; * * \mathrm{P}<0.01 ; * * * \mathrm{P}<0.001$ compared to control

The qualitative composition of protein entering the body of animals can significantly affect the processes of its breakdown and assimilation in the body, so to study the effectiveness of amino acids it is necessary to study the degree of digestibility in the body of both protein and other nutrients. processes are closely related and require comprehensive research (Table 4). 
Table 4. Coefficients of digestibility of nutrients in rations, \%

\begin{tabular}{llllll}
\hline Group & Organic matter & Protein & Fat & Fiber & BER \\
\hline 1 & 76 & 84 & 58 & 17 & 89 \\
2 & 76 & 83 & 58 & 17 & 91 \\
3 & 79 & 86 & 60 & 19 & 92 \\
4 & 77 & 84 & 60 & 18 & 91 \\
\hline
\end{tabular}

As can be seen from the Table 4 data, digestibility of feed nutrients and organic matter were highest in birds of the third group. Levels and ratios of amino acids in the diets of animals of this group contributed to better absorption of protein and fiber in their bodies, compared with animals of the control group by 2 and 3\%, respectively. Comparison of amino acid intake with feed and excretion from the body makes it possible to assess the effectiveness of their use (Table 5). As can be seen from the above data, the efficiency of arginine in the body of young animals was highest in birds of the third group, which is logical given the productivity of birds in this group.

Table 5. Average daily balance of arginine (on average per head).

\begin{tabular}{|c|c|c|c|c|}
\hline \multirow[b]{2}{*}{ Indicators } & \multicolumn{4}{|l|}{ Groups } \\
\hline & 1 & 2 & 3 & 4 \\
\hline Taken with food, $\mathrm{g}$ & $0.570 \pm 0.022$ & $0.570 \pm 0.034$ & $0.570 \pm 0.015$ & $0.570 \pm 0.018$ \\
\hline Retained in the body, $g(+,-)$ & $0.539 \pm 0.017$ & $0.542 \pm 0.005$ & $0.546 \pm 0.008$ & $0.541 \pm 0.014$ \\
\hline Withheld until accepted,\% & 94.6 & 95.1 & 95.8 & 94.9 \\
\hline
\end{tabular}

It should also be noted that with the same intake of arginine in the body of birds, the level of its content, in our opinion, depended on a change in one factor, namely - the amount of lysine in the diet. Data on the metabolism and balance of lysine in the body of replacement young animals are shown in Table 6.

Table 6. Average daily lysine balance (on average per head).

\begin{tabular}{lllll}
\hline Indicators & Groups & & & \\
& $\mathbf{1}$ & $\mathbf{2}$ & $\mathbf{3}$ & $0.542 \pm 0.016$ \\
\hline Taken with food, g & $0.570 \pm 0.012$ & $0.560 \pm 0.021$ & $0.528 \pm 0.008$ \\
Highlighted in the manure, g & $0.046 \pm 0.006$ & $0.038 \pm 0.07$ & $0.021 \pm 0.012$ & $0.027 \pm 0.004$ \\
Retained in the body, g (+, -$)$ & $0.524 \pm 0.011$ & $0.522 \pm 0.012$ & $0.521 \pm 0.003$ & $0.501 \pm 0.002$ \\
Withheld until accepted, $\%$ & 91.9 & 93.2 & 96.1 & 94.9 \\
\hline
\end{tabular}

As can be seen from the above data, the balance and efficiency of lysine use in the body of replacement young were generally the highest in birds of the third group, although the intake of this amino acid was not the highest. The level of lysine absorption in birds of this group was the most effective. It should also be noted that the lowest efficiency of lysine use was observed in birds of the first group, in which the level of intake of this amino acid was the highest. In our opinion, the lower absorption of lysine in birds of the first group is a consequence of the inefficient ratio of this amino acid with arginine, resulting in their antagonistic properties. The relationship between arginine and lysine in the diets of replacement young animals with their live weight in different growing periods is more accurately described by a mathematical model with a nonlinear characteristic (polynomial trend line), which has a higher value of approximation (R2) compared to linear dependence (Table 7).

Table 7. Growth of replacement young stock $(y)$ depending on the ratio of arginine and lysine (x) in the diets.

\begin{tabular}{lll}
\hline Age of the bird, weeks & Regression (R) & Approximation (R ${ }^{2}$ ) \\
\hline $4-8$ & $y=-141.25 x^{2}+316.7 x-176.25$ & 0.96 \\
$9-16$ & $y=-32.41 x^{2}+80.08 x-48.83$ & 0.65 \\
$17-18$ & $y=-34.51 x^{2}+84.45 x-51.05$ & 0.59 \\
\hline
\end{tabular}

It should be noted that in our studies there is a trend: the effect of the ratio of arginine to lysine on the productivity of young animals decreases with age (the level of approximation R2 decreases from 0.9629 at the beginning of cultivation to 0.5901 at the and of cultivation). The derivative of these regression equations allowed us to establish that for these periods the effective ratio of arginine to lysine in the diets of young animals is different and increases up to 16 weeks of age (Figure 1). 


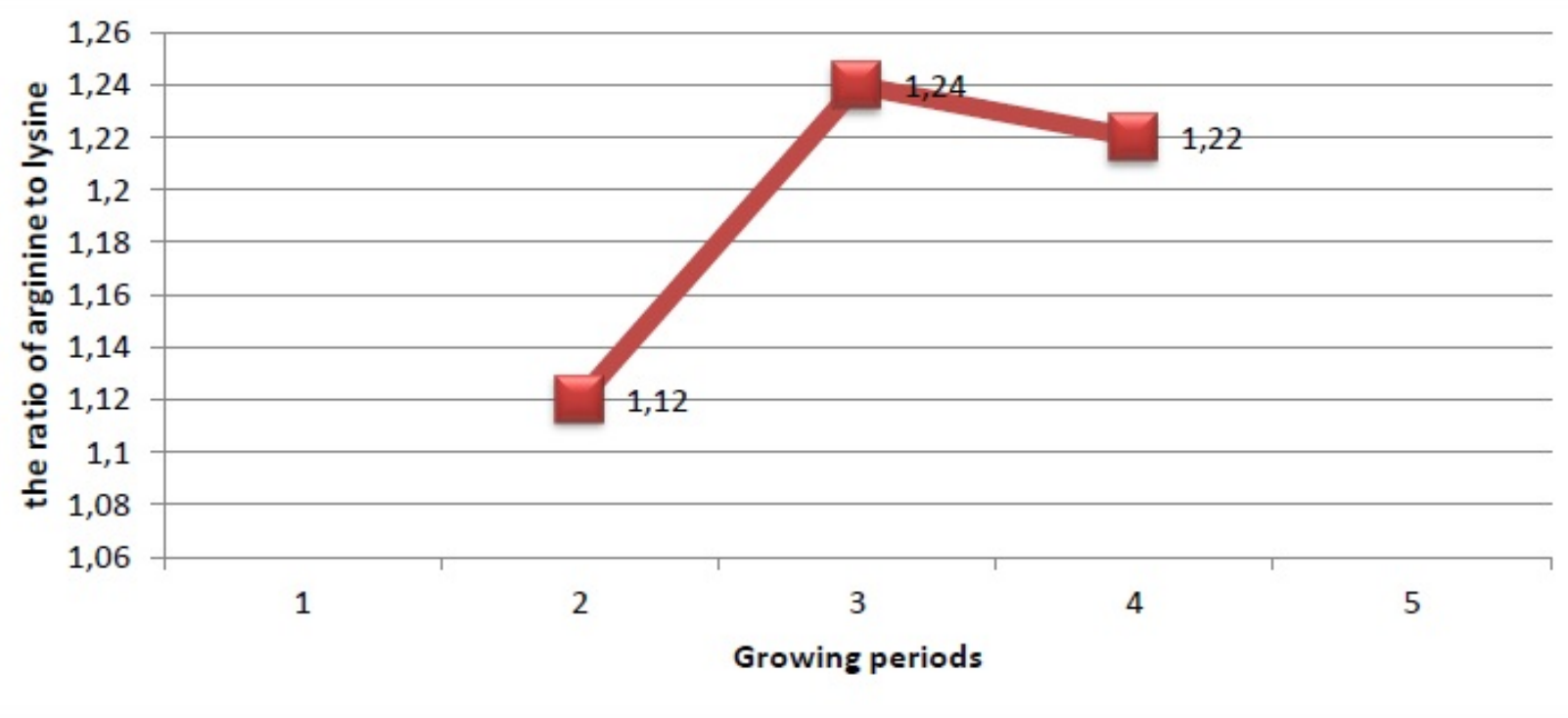

Figure 1. The effective ratio of arginine to lysine.

As can be seen from Figure 1, the effective ratio of arginine to lysine in the diets of replacement chickens changes over time: initially its value increases (in the period from the 9th to the 16th week, although energy and protein levels in the diets decrease), and in the last period of poultry decreases. With the optimal ratio of arginine to lysine (1.12 at the time of physiological experiments), the efficiency of arginine was $95.8 \%$, lysine $-96.1 \%$. It should be noted that in replacement young animals similarly to adult birds with the optimal ratio of arginine and lysine, these two amino acids exhibit synergistic properties, which increases its live weight and assimilation of these amino acids in the body.

\section{Conclusion}

It is established that the feeding of replacement young poultry should be organized taking into account not only the content of amino acids in their diets, but also the ratio between certain amino acids depending on age and predicted productivity of animals. The effective ratio of arginine to lysine in the diets of replacement chickens was experimentally established, which, depending on the rearing period, were: for $1-3$ weeks - 1.0:1, for 4-8 weeks - 1.1: 1, for 9-16 weeks - 1.2:1, and for 17-18 weeks - 1.2: 1 . The content and ratio of arginine and lysine in the diets of replacement young poultry affect their growth and puberty, digestibility of feed nutrients and the effectiveness of the use of amino acids in their body. The use of modern modeling methods and the proposed regression equations allow to predict the content of amino acids in feed for replacement young poultry in accordance with the program of their cultivation and amino acid composition of feed. The balancing of the diets of replacement poultry by amino acid composition should be carried out according to their lysine content, at which an effective ratio with arginine will be achieved.

\section{References}

Al-Saffar, A.A., Rose, S.P. (2002). The response of laying hens to dietary amino acids. World's Poultry Science Journal.,58(5), 209234.

Baker, D.H., Han, Y. (1994). Ideal amino acid profile for chicks during the first three weeks post-hatching. Poultry Science, 73(9), 1441-1447.

Balnave, D, Brake, J. (2002). Re-evaluation of the classical dietary arginine:lysine interaction for modern poultry diets: a review. Worlds Poult Sci J, 58, 275-289. doi: 10.1079 / WPS20020021.

Campos, A.M.A., Rostagno, H.S., Nogueira, E.T., Albino, L.F.T., Pereira, J.P.L., Maia, R.C. (2012). Atualização da proteína ideal para frangos de corte: arginina, isoleucina, valina e triptofano. Revista Brasileira de Zootecnia, 41(2), 326-332.

Carvalho, F.B. de, Stringhini, J.H., Matos, M.S., Café, M.B., Leandro, N.S.M.,... Jardim Filho, R.M. (2015). Egg quality of hens fed different digestible lysine and arginine levels. Brazilian Journal of Poultry Science, 17(1), 63-68. https://doi.org/10.1590/1516635x170163-68

Chamruspollert, M., Pesti, G.M., Bakalli, R.I. (2002). Dietary interrelationships among arginine, methionine, and lysine in young broiler chicks. British Journal of Nutrition, 88(6), 655-660 doi: https://doi.org/10.1079/BJN2002732

Cynober, L., Le Boucher, J., Vasson, M. P. (1995). Arginine metabolism in mammals. Journal of Nutritional Biochemistry, 6, 402413.

Ebrahimi, M., Zare Shahneh, A., Shivazad, M., Ansari Pirsaraei, Z., Tebianian, M., Ruiz-Feria, C.A., Adibmoradi, M., Nourijelyani, K., Mohamadnejad, F. (2014). The effect of feeding excess arginine on lipogenic gene expression and growth performance in broilers. British Poultry Science, 55, 81-88.

Elliot, M.A. (2008). Amino acid nutrition of commercial pullets and layers. California Animal Nutrition Conference, May 21-22, Fresno, California. 139-165.

Ertechini, A.G. (2006). Nutrição de monogástricos. Lavras: UFLA

Fatufe, A., Timmler, R., Rodehutscord, M. (2004). Response to lysine intake in composition of body weight gain and efficiency of lysine utilization of growing male chickens from two genotypes. Poultry Science. 83, 8, 1314-1324.

Fouad, A.M., El-Senousey, H.K., Yang, X.J., Yao, J.H. (2012). Role of dietary L-arginine in poultry production. Int J Poult Sci. 11, 718-729. doi: 10.3923 / ijps.2012.718.729.

Guoyao, Wu. (2014). Dietary requirements of synthesizable amino acids by animals: a paradigm shift in protein nutrition. Journal of Animal Science and Biotechnology, 5(1), 34. doi: 10.1186/2049-1891-5-34 
Jahanian, R., Khalifeh-Gholi, M. (2017). Marginal deficiencies of dietary arginine and methionine could suppress growth performance and immunological responses in broiler chickens. Journal of Animal Physiology and Animal Nutrition. https://doi.org/10.1111/jpn.12695

Kononenko, V.K., Ibatullin, I.I., Patrov, V.S. (2000). Praktykum z osnov naukovykh doslidzhen u tvarynnytstvi (in Ukrainian).

Kriukov, B., Bevziu, V., Polunyna, S. (1997). Vybor kormov s vysokym soderzhanyem proteyna. Ptytsevodstvo, 6, 17-18 (in Russian).

Kryvenok, M.Ia., Ilchuk, I.I. (2016). Teoretychne obgruntuvannia spivvidnoshennia metioninu i treoninu u ratsionakh remontnykh kurchat. Suchasne ptakhivnytstvo, 10-11, 6 (in Ukrainian).

Kryvenok, M.J., Ilchuk, I.I, Mykhalska, V.M. (2017). Prognosis of dietary glycine needs of replacement chicks. Ukrainian Journal of Ecology, 7(4), 46-50, doi: 10.15421/2017_85

Labadan, M.C.Jr., Hsu, K.N., Austic, R.E. (2001). Lysine and arginine requirements of broiler chickens at two- to three-week intervals to eight weeks of age. Poultry Science, 80(5), 599-606.

Lakyn, H.F. (1990). Byometryia. Moscow (in Russian).

Lemme, A. (2009). Amino acid recommendations for laying hens. Lohmann Information, 44(2), 21-32.

Sklan, D., Noy, Y. (2003). Crude protein and essential amino acid requirements in chicks during the first week posthatch. British Poultry Science. 44, 2, 266-274.

De Souza Reis, R., de Toledo Barreto, S.L., da Silva Abjaude, W., Dutra, D.R., Santos, M., de Paula, E. (2012). Relationship of arginine with lysine in diets for laying Japanese quails. Revista Brasileira de Zootecnia. 41, 1. https://doi.org/10.1590/S151635982012000100016

Urdaneta-Rincon M., Leeson S. (2004). Effect of dietary crude protein and b lysine on feather growth in chicks to twenty-one days of age. Poultry Science, 83(10), 1713-1717.

Wecke, C., Pastor, A., Liebert, F. (2016). Validation of the Lysine Requirement as Reference Amino Acid for Ideal In-Feed Amino Acid Ratios in Modern Fast Growing Meat-Type Chickens DOI: 10.4236/ojas.2016.63024

Zampiga, M., Laghi, L., Petracci, M., Zhu, Ch., Meluzzi, A., Dridi, S., Sirri, F. (2018). Effect of dietary arginine to lysine ratios on productive performance, meat quality, plasma and muscle metabolomics profile in fast-growing broiler chickens. Journal of Animal Science and Biotechnology, 9, 79. doi: 10.1186/s40104-018-0294-5

Zampiga, M., Soglia, F., Petracci, M., Meluzzi, A., Sirri, F. (2019). Effect of different arginine-to-lysine ratios in broiler chicken diets on the occurrence of breast myopathies and meat quality attributes. Poultry Science, 98(6), 2691-2697 https://doi.org/10.3382/ps/pey608

\section{Citation:}

Ibatullin, I., Kryvenok, M., Ilchuk, I., Mykhalska, V., Getja, A., Boyarchuk, S. (2020). Metabolism in replacement chickens at different ratios of arginine and lysine. Ukrainian Journal of Ecology, 10(5), 127-132. 